\title{
UNSCHEDULED RETURN VISITS TO THE EMERGENCY DEPARTMENT: INCIDENCE, REASONS, POSSIBLE SOLUTIONS
}

\author{
Aušra Bilotienė-Motiejūniene் ${ }^{1}$, Andrius Klimašauskas ${ }^{2}$, Eglẻ Kontrimavičiūtė ${ }^{3}$, \\ Rūta Janulevičienè ${ }^{3}$, Dovilè Majauskyte் ${ }^{3}$, Rimantas Stukas ${ }^{4}$ \\ ${ }^{1}$ Institute of Health Sciences, Faculty of Medicine, Vilnius University, Lithuania, Vilnius University \\ Hospital Santaros Klinikos, Lithuania, ${ }^{2}$ Centre of Emergency Medicine, Vilnius University, \\ Lithuania, ${ }^{3}$ Centre of Anaesthesiology, Intensive therapy and Pain Management, Vilnius University, \\ Lithuania, ${ }^{4}$ Institute of Health Sciences, Faculty of Medicine, Vilnius University, Lithuania
}

Keywords: return visits, returns, unscheduled returns, revisits, unplanned return visit, readmission, Emergency Department.

\begin{abstract}
Summary
The rate of attendance at the Emergency Department (ED) is annually increasing worldwide. Return visits constitute $5 \%$ of all visits to the ED. The aim of this review is to determine the incidence and reasons of the readmissions to the ED as well as to provide possible solutions in order to avoid unscheduled return visits. Therefore, literature review was conducted using the databases of Medline, PubMed, Cinahl and Cochrane (from inception to September, 2019). Various keywords were used in the advanced search: return visits, unscheduled returns, revisits, unplanned return visits, readmission. Approximately 40 articles that met the inclusion criteria were selected for this paper. Various time frames -48 hours, 72 hours, 7 days, 30 days, 180 days - were applied for the evaluation of return visits. Unplanned return visits (URV) are more likely to happen in elderly patients, in those who have the underlying disease and in younger children aged less than six years. The main causes of the return visits are the factors related to the patients or to the physicians (disease progression, medical errors, delayed diagnosis, or misdiagnosis). The highest return rates according to the medical conditions have been recorded for the abdominal pain, urinary tract infections, and migraine. Hospitalized patients constitute up to $40 \%$ of returning patient cases. There is no consensus on the term or time frame employed to classify the return visits to the ED. Most commonly
\end{abstract}

used readmission time frames reveal the evidence regarding the factors related to patients, illnesses, and staff. The future researches should focus on patient education, clinicians and healthcare providers in order to facilitate the creation of predictive models for reduction of unplanned readmissions. These proceedings will significantly reduce the expenses, both personnel resources and institutional costs.

\section{Introduction}

The annual increase in the Emergency Department (ED) admissions significantly boost the expenses worldwide. Admission rates have a close connection with unemployment rates, availability to receive the healthcare services from alternative primary care service providers, and urban/ rural status of the patients. These rates vary widely among different healthcare systems. However, the reasons of return visits to the ED are complex and involve such causes as disease progression, medical errors, delayed diagnosis, or misdiagnosis. High rate of unplanned return visits (URV) may be an indicator of poor medical care, especially requiring admission to an intensive care unit [1]. Monitoring of the URV to the ED is a quality indicator of emergency care, both of individual clinicians and healthcare organization systems.

There is no solid consensus on a term referring to the URV to the ED. A wide variety of keywords, such as return visits, returns, revisits, unscheduled return visits, unplanned reattendances, unplanned revisits can be found in the medical literature, referring to the same phenomena [2-7].

There is also no unequivocal agreement of all the researchers what time frame coresponds to a return visit [8]. Seventy-two hours is the most frequently mentioned period of time in the literature since 1987 and it has been widely 
used all over the world to designate the unplanned visits to the $\operatorname{ED}[9,10]$. Now this time frame is questioned due to the lack of validity and longer time frames are recommended -7 days, 9 days, 1 month [11,12]. In the articles, selected for this review, the interval varies from 48 hours to 180 days, while the majority of authors choose the period of 30 days. Such tendency to shift to a lengthy time frame is related to the higher readmission rates in a longer period as Hutchinson et al. have also noted in the recent review [13]. Consequently, additional causes of the ED readmissions could be detected and managed.

Moreover, review of the currently available scientific literature suggest that difficulties in analyzing the data arise when the classification lacks specificity or when the URV are not related to the first visit issues [14]. Further analysis, clear time frame, and investigation from the perspective of patients are required to explain the causes of the URV.

The aim of this research is to describe the character and issues of the readmissions to the ED as well as to present proposals concerning the decrease of the URV. To achieve this aim, the following objectives have been set: to provide a broad review of literature on the URV; to determine the incidence and causes of the URV; to introduce possible solutions for patients suffering from the URV.

\section{Research methodology}

Four databases (Medline, PubMed, Cinahl, and Cochrane) were used for searching of articles which had been published in 2009-2019. The researchers had chosen the following keywords: return visits, unscheduled returns, revisits, unplanned return visits, readmission. The studies, which are focusing on hospital ward readmissions, readmissions of specific rare conditions, investigating, and the frequent ED visitors, were rejected. There were 133 publications that were selected for the further detailed analysis; they investigate readmissions in the setting of the ED in developed countries,. After thorough discussion among all the authors, 38 scientific papers were included in the final review.

\section{Discussion}

Detailed analysis of medical literature revealed four groups of factors associated with the URV rate similarly. The arrangement of related factors is as follows: 1) patientrelated, 2) illness-related, 3) organization-related, 4) clinician-related. Before developing the interventions aimed at reducing the frequency of readmissions and using this rate as a reliable and reproducible quality indicator, a thorough analysis and understanding how these criteria contribute to the URV is required. In addition, the adoption of a standardized grading and measurement system will also help researchers to produce prognostic models that allow the prediction of readmission rates in the future [15].

Patient-related factors. When discussing the underlying causes of the unplanned returns to the ED, the patient-related factors are one of the main determinants. Such factors as age, purpose of attendance, or earlier experience of received emergency medicine services are likely to influence decision making when the patient arrives to the ED [16-18]. Patients of the opposite age, for example, the elderly and the children, might have a higher risk of the unplanned returns because of the social as well as the medical problems. A study of adults has showed that the patients over 65 years old who have been assessed as "less acute" in the process of triage, returned to the ED 16 times more often than the control group (patients aged 45 to 50 years old). If a patient is older than 85 years and during the triade process he/she is included in the category of "low acuity" patients, the risk of the URV arises within a period of 14 days [17]. Also, the recent observational study has found that such factors as young patient's age, multiple previous hospitalizations and co-morbidities are related to the higher number of patient revisits in the field of pediatrics [16]. Furthermore, some patients with non-urgent health conditions attend the ED in order to receive comprehensive health care, good service quality and accessibility; they are encouraged by previous positive experience as well. This need to attend the ED can emerge in patients with a lower level of education or those affected by relevant psychosocial factors. According to the degree of patient confidence in their own primary care provider, the decision to get a second opinion at the ED during the subsequent visit is made [18].

Illness- or complaint-related factors. These factors constitute the largest group of readmission causes. During their study, Wu et al. have found that more than $80 \%$ of all readmission rates (on average 5.47\%) are associated with progression of illness and symptoms [7]. Moreover, complaints are pretty highly connected to abdominal pain rating as a state related to the ED revisits. It may be possible that abdominal pain which manifests as a symptom of the particular disease is obscure and might change over time. For this reason, patients with non-specific abdominal pain are more likely to revisit the ED in comparison to people suffering from non-specific chest pain for whom it is probably simplier to identify the risk and to diagnose the existing illness $[19,20]$. The progression of symptoms and non-identified causes of the illness are more likely to lead to higher rates of risk for the URV as well. Furthermore, if their health problems are not resolved, patients with long-term indeterminate symptoms might become regular attenders of the ED [21]. As the qualitative study which had been conducted 
at the University of British Columbia showed, perception of the illness course and the progression of symptoms, also expectations for quality of the health care services provided in the ED impact the revisitation rate which is associated to the illnesses among pediatric patients [22]. The natural course of the disease is also related to the returns. The patients with acute illnesses, such as appendicitis, might return 24 or 48 hours after their first visit when the disease course and the symptoms are typical, however, the patients with congestive heart failure might present themselves to the ED several times before an appropriate treatment plan and recommendations for the adherence to this plan are constructed. Also, the shorter time frames used for recording the revisits better reflect the returns which occur due to acute illnesses whereas the returns of the patients diagnosed with chronic diseases usually happen repeatedly in the longer periods of time [23].

Organization-related factors. The group of factors related to the hospital's work organization are treated as avoidable [7]. The extent of their distribution depends on the particular literature source and includes the effective communication of health care employees, patient education and appropriate follow-up prescription, at discharge both from hospital and the ED [24,25]. In terms of the patient's education and the communication between health care specialist and the patient, clear guidelines provided before the discharge and the conveyance of information about alternative locations of health care for future medical needs reduce the number of the URV within 30 days at discharge both from hospital and the ED [24]. Moreover, the follow-up is a relevant method used to reduce the reattendance rate, but in order to get the maximum benefit it is highly important to choose an appropriate intervention approach. The randomized controlled research which had been performed by Patel et al. showed that the patients older than 65 years are more likely to answer the telephone calls meanwhile the patients aged less than 65 years are more likely to respond to emails. Nevertheless, identifying the optimal population at which the interventions should be targeted is an object of further studies and discussions [25].

Clinician-related factors. The data that has been derived from scientific literature shows that the revisits associated with physicians vary widely. The capability of the ED physician to identify the diagnose correctly and to initiate the effective treatment is based on the combination of all factors mentioned above. This process is especially difficult when such communication problems as language barriers are present [26]. Also, early discharge from the ED is linked to the readmissions and it is possible that these mistakes in treatment might be foreseen if the patients are monitored for a longer term before the discharge [7]. Another impor- tant process which is related to clinician factor and which could have resulted the higher rates of the URV is safety netting. An example of it can be a situation when the patients with certain conditions such as abdominal pain are asked to return to the ED after a period of time if the symptoms get worse. A recent Dutch study suggests that re-evaluation which has been performed within 30 hours in 306 patients out of 356 people with non-specific abdominal pain resulted in relevant clinical diagnosis and the following treatment change from 21 to 22 percent of cases [19]. All in all, it is doubtful whether safety netting can be treated as a form of reattendance and this situation clearly demonstrates a case of system failure.

\section{Measures to reduce ED revisits}

As multiple factors as well as causes of repeated visits to the ED have been identified, measures for minimising the number of readmissions can be suggested. These measures are divided into three groups: follow-up, interventions to improve physical status of patients, and education.

Studies have proposed several types of follow-up which include telephone calls made and emails sent by a nurse or a pharmacist, a home visit carried out by a nurse and planned return visits. The purpose of a call is to provide the additional information, clarification on medication regimens, instructions for the further medical care [24]. Focusing on the evaluation of daily activities and concentration on the rehabilitation plan should be emphasized for older adults [27]. The accompanying nurse has been suggested for leading the patients home after discharge, arranging their medications and the subsequent medical visits [28]. Planned follow-up visits were efficient in patients with abdominal pain, as a quarter of them had their diagnosis changed during the secondary evaluation [19]. The efficacy of this type of intervention remains unclear. Some authors find it ineffective while others note that the communication has reduced revisits to the ED so the latter authors even suggest using an automated calling system as very few patients have questions [25,28-30].

Certain interventions have been suggested to improve the general health of the patient. Physical therapy was found to be beneficial in elderly adults, admitted to the ED because of the falls [31]. However, this kind of intervention should be limited because it causes the general weakness and pain, often associated with numerous medical conditions [31].

The lack of education regarding the expected further course of the disease is highlighted as one of the most important factors causing the patient to return to the ED. Also, patients who feel uncertain about the quality of healthcare services provided, tend to revisit the ED more often [32]. Both spoken and written instructions are recommended to 
be given before the discharge from the ED. The instructions should include the pre-prepared information on diagnosis, prescribed medications and recommendations concerning the date on which a patient should seek for medical attention again [33]. The visits to the ED can also be reduced by information provision on medical services which are available in case of non-emergency illness [34].

Predicting models of revisits to the ED. Technologies used to collect the health information, such as electronic health records or health information exchange capabilities, provide better access to the patient information among organizations. In addition, more and more public sources comprised of data describing the social determinants of health subjects are emerging [35]. Discharge disposition is an important factor that influences the risk of future revisit to the ED. An older adult with multiple comorbidities such as diabetes, hyponatremia $(<135 \mathrm{mmol} / \mathrm{l})$ and dehydration or foreign speaker who also returned 2 times or more to the ED within 6 month period are at higher risk than an individual with few comorbidities and diagnosed with the tension headache after being discharged [36]. Such information should be reflected in the illness severity score that would be used to predict the possible outcomes. On the other hand, it is extremely difficult to create a general model because of the large differences in work's organization of different institutions. Although a constructive prediction model of revisits has not yet been developed, the early ED reattendances are one of the strongest predictors of adverse outcomes in older adults [37].

Limitations. The main aim of this literature review is to identify the subjects that could be used to create new amendments instead of designating specific causes or even blaming certain circumstances. First of all, the definition of reattendance is rarely clearly described in the reviewed medical literature. This situation might cover the exclusion of patients whose attendance was unrelated to previous condition or those who were diagnosed with different illnesses during the revisit. Such division has its specific advantages and disadvantages, but the term can hardly be standardized and as a result it appears confusing to use the URV rate as a quality indicator [38]. Another limitation of revisit studies should be noted because of a number of patients who subsequently attended from other health care facilities and have not been given much consideration [22]. On that point, the URV rate may cause the devaluation of the actual representation extent in healthcare overall. Moreover, there is necessity to interrupt the unplanned returns of the regular ED attenders or "frequent flyers" [21]. Even if this group of patients increase all the URV rate, they significantly distort the data, so their situation should be discussed separately.
Therefore researches specifically oriented to the frequent attenders or particular disease processes were not included in this survey.

\section{Conclusions}

There is no consensus on the term or time frame which should be employed to classify return visits to the ED. The most commonly used readmission time frames reveal the findings of patient-related, illness-related and staff-related factors. Future researches should focus on enhancement of patient education, facilitation to clinicians and healthcare providers for predictive model creation in order to reduce the unplanned readmissions. These courses of action will significantly reduce the expenses, both personnel resources and institutional costs.

\section{References}

1. Pham JC, Kirsch TD, Hill PM, DeRuggerio K, Hoffmann B. Seventy-two-hour returns may not be a good indicator of safety in emergency department: a national study. Acad Emerg Med 2011;18(4):390-397.

https://doi.org/10.1111/j.1553-2712.2011.01042.x

2. Shy BD, Shapiro JS, Shearer PL, Genes NG, Clesca CF, Strayer RJ, Richardson LD. A conceptual framework for improved analyses of 72-hour return cases. Am J Emerg Med 2015;33(1):104-107.

https://doi.org/10.1016/j.ajem.2014.08.005

3. Easter JS, Bachur R. Physicians' assessment of pediatric returns to the Emergency Department. J Emerg Med 2013;44(3):682-688. https://doi.org/10.1016/j.jemermed.2012.05.011

4. Duseja R, Bardach NS, Lin GA, Yazdany J, Dean ML, Clay TH, Boscardin WJ, Dudley RA. Revisit rates and associated costs after emergency department encounter: a multistate analysis. Ann Internal Med 2015;162(11):750-756.

https://doi.org/10.7326/M14-1616

5. Verselst S, Pierloot S, Desruelles D, Gillet JB, Bergs JI. Shortterm unscheduled return visits of adult patients to the emergency department. J Emerg Med 2014;47(2):131-139.

https://doi.org/10.1016/j.jemermed.2014.01.016

6. Goh GL, Huang P, Kong MCP, Chew SP, Ganapathy S. Unplanned reattendances at the paediatric emergency department within 72 hours: a one-year experience in KKH. Singapore Med J 2016;57(6):307-313.

https://doi.org/10.11622/smedj.2016105

7. Wu CL, Wang FT, Chiang YC, Chiu YF, Lin TG, Fu LF, Tsai TL. Unplanned emergency department revisits within 72 hours to a secondary teaching referral hospital in Taiwan. J Emerg Med 2010;38(4):512-517. https://doi.org/10.1016/j.jemermed.2008.03.039

8. Han CY, Chen LC, Bernard A, Lin CC, et al. Early revisit to the emergency department: an integrative review. J Emerg Nurs 
2015;41(4):285-295.

https://doi.org/10.1016/j.jen.2014.11.013

9. Lerman B, Kobernick MS. Return visits to the emergency department. J Emerg Med 1987;5(5):359-362.

https://doi.org/10.1016/0736-4679(87)90138-7

10. Aaronson E, Benzer T, Borczuk P. Seventy-two-hour returns are not useful in identifying emergency department patients with a concerning intra-abdominal process. J Emerg Med 2016;50(4):560-566.

https://doi.org/10.1016/j.jemermed.2015.11.015

11. Rising KL, Victor TW, Hollander JE, Carr BG. Patient returns to the emergency department: the time-to-return curve. Acad Emerg Med 2014;21(8):864-871.

https://doi.org/10.1111/acem.12442

12. Anderson T, Thombley R, Dudley RA, Lin GA. Trends in hospitalization, readmission and diagnostic testing of patients presenting to the emergency department with syncope. Ann Emerg Med 2018;72(5):523-555.

https://doi.org/10.1016/j.annemergmed.2018.08.430

13. Hutchinson C, Mccloughen A, Curtis K. Incidence, characteristics and outcomes of patients that return to Emergency Departments. An integrative review. Australas Emerg Care 2019;22(1):47-68.

https://doi.org/10.1016/j.auec.2018.12.003

14. Nuñez S, Hexdall A, Aguirre-Jaime A. Unscheduled returns to the emergency department: an outcome of medical errors? Qual Saf Health Care 2006;15(2):102-108.

https://doi.org/10.1136/qshc.2005.016618

15. Khalifa M, Magrabi F, Gallego B. Developing a framework for evidence-based grading and assessment of predictive tools for clinical decision support. BMC Med Inform Decis Mak 2019;19(1):207.

https://doi.org/10.1186/s12911-019-0940-7

16. Kim BS, Kim JY, Choi SH, Yoon YH. Understanding the characteristics of recurrent visits to the emergency department by paediatric patients: a retrospective observational study conducted at three tertiary hospitals in Korea. BMJ Open 2018;8(2): 018208 .

https://doi.org/10.1136/bmjopen-2017-018208

17. Hendin A, Eagles D, Myers V, Stiell IG. Characteristics and outcomes of older emergency department patients assigned a low acuity triage score. CJEM 2018;20(5):762-769.

https://doi.org/10.1017/cem.2018.17

18. Goodridge D, Stempien J. Understanding why older adults choose to seek non-urgent care in the emergency department: the patient's perspective. CJEM 2019;21(2):243-248.

https://doi.org/10.1017/cem.2018.378

19. Boendermaker AE, Coolsma CW, Emous M, Avest E. Efficacy of scheduled return visits for emergency department patients with non-specific abdominal pain. Emerg Med J 2018;35(8):499-506. https://doi.org/10.1136/emermed-2017-207338

20. Potezny TM, Horwood CM, Hakendorf P, Papendick C, Thompson $\mathrm{CH}$. Predicting re-presentation following discharge from the emergency department with non-specific chest pain. Emerg Med Australas 2018;30(2):193-199.

https://doi.org/10.1111/1742-6723.12912

21. Diplock G, Ward J, Stewart S. et al. The Alice Springs Hospital Readmission Prevention Project (ASHRAPP): a randomised control trial. BMC Health Serv Res 2017;17(1):153.

https://doi.org/10.1186/s12913-017-2077-7

22. Meyer-Macaulay CB, Truong M, Meckler GD, Doan QH. Return visits to the pediatric emergency department: a multicentre retrospective cohort study. CJEM 2018;20(4):578-585.

https://doi.org/10.1017/cem.2017.40

23. Honeyford K, Aylin P, Bottle A. Should emergency department attendances be used with or instead of readmission rates as a performance metric?: comparison of statistical properties using national data. Med Care 2019;57(1):e1-e8.

https://doi.org/10.1097/MLR.0000000000000899

24. Jack BWC, Anthony VK, Greenwald D, Sanchez JL, Johnson GM, Forsythe AE. et al. A reengineered hospital discharge program to decrease rehospitalization. Ann Internal Med 2009;150(3):178-187.

https://doi.org/10.7326/0003-4819-150-3-200902030-00007

25. Patel PB, Vinson DR, Gardner MN, Wulf DA, Kipnis P, Liu V, Escobar GJ. Impact of emergency physician-provided patient education about alternative care venues. Am J Manag Care 2018;24(5):225-231.

26. Rawal S, Srighanthan J, Vasantharoopan A, Hu H, Tomlinson G, Cheung AM. Association between limited English proficiency and revisits and readmissions after hospitalization for patients with acute and chronic conditions in Toronto, Ontario, Canada. JAMA 2019;322(16): 1605-1607.

https://doi.org/10.1001/jama.2019.13066

27. Nielsen LM, Maribo T, Kirkegaard H, Petersen KS, Oestergaard LG. Development of a complex intervention aimed at reducing the risk of readmission of elderly patients discharged from the emergency department using the intervention mapping protocol. BMC Health Serv Res 2018;18(1):588.

https://doi.org/10.1186/s12913-018-3391-4

28. Lembeck MA, Thygesen LC, Sørensen BD, Rasmussen LL, Holm EA. Effect of single follow-up home visit on readmission in a group of frail elderly patients - a Danish randomized clinical trial. BMC Health Serv Res 2019;19(1):751.

https://doi.org/10.1186/s12913-019-4528-9

29. Chen CJ, Cochon L, Tat S, Green-Hopkins I. Telephone followup after pediatric emergency department discharge - does it impact the likelihood of return visits? WestJEM 2019;20(5.1).

30. Asthana V, Sundararajan M, Ackah RL, et al. Heart failure education in the emergency department markedly reduces readmissions in un- and under-insured patients. Am J Emerg Med 2018;36(12):2166-2171. 
https://doi.org/10.1016/j.ajem.2018.03.057

31. Lesser A, Israni J, Kent T, Ko KJ. Association between physical therapy in the emergency department and emergency department revisits for older adult fallers: a nationally representative analysis. J Am Geriatr Soc 2018;66(11):2205-2212.

https://doi.org/10.1111/jgs.15469

32. Rising KL, LaNoue MD, Gerolamo AM, et al. Patient uncertainty as a predictor of 30 day return emergency department visits: an observational study. Acad Emerg Med 2019;26(5):501-509. https://doi.org/10.1111/acem.13621

33. Taylor DM, Cameron PA. Discharge instructions for emergency department patients: what should we provide? J Accid Emerg Med 2000;17(2):86-90.

https://doi.org/10.1136/emj.17.2.86

34. Litwin S, Canning M, Clemens J, et al. Virtual care as a quality improvement intervention to reduce low acuity return visits to the paediatric emergency department. Paediatr Child Health 2019;24 (Supplement 2):e43-e44.

https://doi.org/10.1093/pch/pxz066.113

35. Vest JR, Ben-Assuli O. Prediction of emergency department revisits using area-level social determinants of health measures and health information exchange information. Int J Med Inform 2019;129(9):205-210. https://doi.org/10.1016/j.ijmedinf.2019.06.013

36. Obiagwu C, Rabice S, Ambesh P, Lamikanra O, Nwanyanwu C, Alliu S, Kakar P, Saxena A, Adzic A, Moskovits N, Hecht M, Shetty V. Developing a targeted approach to 30 day chf readmissions. JACC 2018;71(11 Supplement):A721.

https://doi.org/10.1016/S0735-1097(18)31262-2

37. Gelder J, Lucke JA, de Groot B, Fogteloo AJ, Anten S, Heringhaus C, Dekkers OM, Blauw GJ, Mooijaart SP. Predictors and outcomes of revisits in older adults discharged from the emergency department. J Am Geriatr Soc 2018;66(4):735-741. https://doi.org/10.1111/jgs.15301

38. Sills MR, Macy ML, Kocher KE, Sabbatini AK. Return visit admissions may not indicate quality of emergency department care for children. Acad Emerg Med 2018;25(3):283-292.

https://doi.org/10.1111/acem.13324

\section{NEPLANUOTI PAKARTOTINIAI VIZITAI SKUBIOS PAGALBOS SKYRIUJE: DAŽNIS, PRIEŽASTYS, GALIMI SPRENDIMO BŪDAI}

A.Bilotienè-Motiejūnienė, A.Klimašauskas,

E.Kontrimavičiūtè, R.Janulevičienė, D.Majauskytė, R.Stukas

Raktažodžiai: pakartotinis vizitas, neplanuotas grịžimas ị skubios pagalbos skyrių, nenumatytas vizitas, neplanuotas pakartotinis vizitas, grịžimas.

\section{Santrauka}

Besikreipiančių į skubios pagalbos skyrių pacientų skaičius visame pasaulyje kasmet didèja. Mokslinèje literatūroje pateiktais duomenimis, neplanuotų grįžimų ị šị skyrių skaičius svyruoja, sudarydamas 5 proc. visų pakartotinių vizitų. Šios literatūros apžvalgos tikslas - nustatyti pakartotinių vizitų skubios pagalbos skyriuje dažnị ir priežastis bei ieškoti galimų sprendimo būdų, siekiant sumažinti neplanuotų grị̌zimų skaičių. Literatūros paieška atlikta naudojantis duomenų bazėmis MEDLINE, PubMed, CINAHL ir Cochrane (rinkti moksliniai straipsniai, pasirodę iki 2019 metų rugsèjo mènesio imtinai). Vykdant išplèstinę paiešką, buvo vartojami ìvairūs terminai: pakartotinis vizitas, neplanuotas grị̌imas ị skubios pagalbos skyrių, nenumatytas vizitas, neplanuotas pakartotinis vizitas, grịžimas. Šiai apžvalgai atrinkta apie 40 straipsnių, kurie atitiko įtraukimo kriterijus. Vertintas pakartotinių vizitų skubios pagalbos skyriuje skaičius ịvairiais laikotarpiais - per 48 valandas, 72 valandas, 7 dienas, 30 dienų, 180 dienų. Remiantis literatūros duomenimis, tikètina, kad pakartotinai ị skubios pagalbos skyrių dažniau grižta vyresnio amžiaus žmonès, sergantys lètine liga pacientai bei jaunesni nei šešerių metų vaikai. Neplanuotų pakartotinių vizitų skaičius priklauso nuo veiksnių, kuriuos lemia pacientai ir medicinos personalas (natūralaus ligos progresavimo, medicininių klaidų, ne laiku ar neteisingai nustatytos diagnozès). Didžioji dalis grịžtančiujų skundèsi nespecifiniu pilvo skausmu. Pakartotinai apsilankiusių pacientų hospitalizacijos dažnis siekè 40 proc. Nèra bendro susitarimo dèl pakartotinị vizitą ị skubios pagalbos skyrių apibrèžiančios sąvokos termino ir laikotarpio. Dažniausiai neplanuotiems grị̌imams vertinti naudojami laikotarpiai nurodo, kad įtaką dažniui turi faktoriai, susiję su pacientais, ligos ir simptomų eiga bei medicinos personalu. Tolesni tyrimai turètų būti sutelkti ị pacientų švietimo efektyvumą ir pakartotinio sugrịžimo prognozès modelių kūrimą bei diegimą sveikatos priežiūros įstaigose. Tai galètų sumažinti žmogiškiesiems ištekliams skirtas išlaidas ir medicinos paslaugų ịkainius.

Adresas susirašinèti: egle.kontrimaviciute@santa.lt

2020-01-05 